\title{
Fascynujące ścieżki filozofii prawa, pod red. Jerzego Zajadło, Wydawnictwo Prawnicze LexisNexis, Warszawa 2008, 328 stron.
}

Książka jest wspólnym dziełem pracowników naukowych Wydziału Prawa i Administracji Uniwersytetu Gdańskiego z różnych dziedzin prawa. Wśród autorów są zarówno teoretycy prawa, jak i prawnicy praktycy, których łączy praca akademicka. Redaktorem naukowym pracy zbiorowej jest Jerzy Zajadło, zajmujący się głównie teorią i filozofią prawa, a więc dyscyplinami uznanymi za kluczowe z punktu widzenia problemów podjętych w pracy. To właśnie tytułowa filozofia prawa staje się dyscypliną łączącą, w tym przypadku inne, często bardzo wyspecjalizowane dziedziny prawnicze. Współautorami książki obok teoretyków i filozofów prawa są przedstawiciele dogmatycznych nauk prawnych, takich jak: prawo karne materialne i procesowe, prawo międzynarodowe publiczne, prawo europejskie, prawo konstytucyjne, prawo gospodarcze publiczne. Podejmowane przez nich zagadnienia wiążą się także z szeroko rozumianym prawem cywilnym i administracyjnym oraz historią prawa, zważywszy na odwoływanie się do skomplikowanych spraw i związanych z nimi ciekawych procesów z przeszłości.

Systematyka pracy jest przemyślana. Wszystkie rozdziały mają podobne tytuły (Prawo kontra...), wskazujące na problematykę przeciwstawiania prawa jakiemuś zagadnieniu posiadającemu własny system normatywny, odnoszącemu się przy tym do rozmaitych wartości. Każdy z rozdziałów składa się z Uwag wstępnych redaktora naukowego jako wprowadzenia oraz dwóch podrozdziałów noszących własne tytuły, w których przez kazuistyczne przykłady omawiane są trudne do sądowego rozstrzygnięcia przypadki. Obok trzynastu rozdziałów jest Wprowadzenie mające wyjaśnić: Co to są hard cases? i Zakończenie posiadające również tytuł (Prawo kontra człowiek) oraz identyczną strukturę wewnętrzną jak wcześniejsze rozdziały.

We Wprowadzeniu Jerzy Zajadło wyjaśnia, co to są hard cases, odwołując się do podzielonych zdań w tej kwestii najwybitniejszych przedstawicieli współczesnej filozofii prawa, a zwłaszcza teorii R. Dworkina, H. L. A. Harta, ale także takich myślicieli, jak: M. McCormick, A. Peczenik, G. Radbruch, czy polskich, jak np.: M. Król, J. Stelmach, J. Wróblewski, M. Zirk-Sadowski i wielu innych prawników wypowiadających się w sprawie rozwiązywania trudnych przypadków. Redaktor pracy zaznacza, że hard cases wiążą się przede wszystkim z systemem anglosaskim (prawa precedensowego), ale nie tylko (s. 7 i 8), ponieważ wskazywane w książce konkretne przykłady odnoszą się także do systemów prawa stanowionego - kontynentalnego, w tym prawa polskiego.

Według niego hard cases (trudne przypadki) pojawiają się tam, gdzie system prawny zderza się z innym systemem o charakterze normatywnym. Bez praktycznego zastosowania rozwiązań filozoficzno-prawnych nie da się ich rozwiązać. Dlatego podając dwa różne sposoby ich rozwiązywania J. Zajadło omawia koncepcję Harta i integralną teorię 
prawa R. Dworkina, i wskazuje zarazem na paradoks z nich wynikający, a mianowicie na to, że pozytywista Hart „poszukuje rozwiązania trudnych przypadków na gruncie norm pozaprawnych, natomiast niepozytywista Dworkin - na gruncie zasad i wskazówek...” (s. 10). Pierwszy zatem zakłada wyjście poza system, ale nie poza standardy stosowania prawa, przyjmując istnienie tylko reguł. Natomiast drugi obok reguł, które uważa za niewystarczające, aby wydać słuszne orzeczenie, przyjmuje konieczność odwołania się do zasad i wskazówek „drzemiących” w systemie prawa (s. 9-10). Inną istotną różnicą w ich koncepcjach jest przyjęcie przez Dworkina, w przeciwieństwie do Harta, tylko jednego prawidłowego (słusznego) rozwiązania trudnego przypadku (s. 11). Zdaniem redaktora książki, w sprawach trudnych mamy do czynienia z tzw. „poszukiwaniem prawa”, w trakcie którego pojawia się dyskurs prawniczy przenoszący nas w sferę de lege ferenda, czyli prawa postulowanego, prawa, jakie powinno być (obowiązywać), a do tego niezbędna jest właśnie filozofia prawa (s. 10 i 11).

Wszyscy autorzy zgadzają się, że hard cases nie dotyczą wyłącznie sfery stosowania prawa, ale także jego tworzenia, obowiązywania i przestrzegania jako pewnego rodzaju fenomenu (s. 13). Trafnie zauważa recenzent książki Michał Balcerzak („Państwo i Prawo" 2009, z. 6, r. LXIV, s. 110-112), że autorzy rozdziałów prezentując wybrane trudne przypadki, odstępują często od dyskursu prawniczego na rzecz dyskursu etycznego. Potwierdza to dodatkowo interdyscyplinarny charakter wynikających z nich problemów. Zgodzić się należy w powyższej kwestii ze spostrzeżeniem J. Zajadło, który wskazał, że dyskurs prawny jest jednocześnie dyskursem aksjologicznym, a o istocie tego pierwszego „decyduje nie konieczność bezpośredniego związku z obowiązującym prawem, lecz prawnie relewantny przedmiot dyskursu w ramach tak pojętych trudnych przypadków” (s. 14). W książce widać zatem doskonale silne powiązania prawa z filozofią, a zwłaszcza takimi jej działami, jak: etyka, w tym etyka prawa i etyka prawnicza, aksjologia jako ogólna teoria wartości, w tym aksjologia prawa, a także logika (logika dla prawników), której wykorzystywanie przy rozwiązywaniu trudnych przypadków jest bezcenne i niepodważalne. W powyższym kontekście należy zaznaczyć, że przy rozwiązywaniu hard cases teoria prawa, która analizuje, systematyzuje i generalizuje prawo obowiązujące nie wystarcza, potrzebna jest do tego filozofia prawa, etyka prawa i aksjologia prawa, poszukujące ideału prawa jako harmonii trzech - zdaniem Gustawa Radbrucha - jego elementów: bezpieczeństwa, celowości i sprawiedliwości (s. 17). Do znalezienia tej harmonii potrzebny jest rozum praktyczny, który w ujęciu Immanuela Kanta i neokantystów ma nam pomóc w poszukiwaniu odpowiedzi na pytanie: Co powinienem czynić? W przeciwnym razie, tam gdzie dochodzi do sprzeczności między powyższymi elementami ideału prawa, pojawiają się właśnie hard cases.

Zamiarem autorów książki jest skłonić czytelnika do głębszej refleksji i własnych przemyśleń (s. 15) na temat trudnych przypadków, przy rozwiązywaniu których należy „sięgać do mądrości i zdrowego rozsądku”(s. 14). W tym celu każdy z rozdziałów książki, z wyjątkiem ostatniego jako zakończenia, zawiera pytania i problemy stawiane przez autorów. Zaznaczyć trzeba, że niektóre ważne przy konkretnych przypadkach pytania 
i problemy często pojawiają się już w poszczególnych tekstach. Na uwagę zasługuje wskazana w podrozdziałach bogata literatura, zwłaszcza anglojęzyczna oraz orzecznictwo: polskie i zagraniczne. Język lektury jest w większości typowo prawniczy - precyzyjny i odznacza się dużym kunsztem. Nie znaczy to, że będzie niezrozumiały dla nieprawników. Wręcz przeciwnie, trudne przypadki są omówione jasno i w sposób mogący zaciekawić nawet laika. Na pochwałę zasługuje wybór spraw określonych jako trudne, które odnoszą się do słynnych spraw z przeszłości lub dotykają problematyki istotnej dla współczesnego świata. Cytaty, w tym określenia i terminy łacińskie, są znakomicie dobrane i wpasowane w całokształt tekstu, nadając mu żywy charakter.

W rozdziale I (Prawo kontra prawo) Jerzy Zajadło snuje refleksję na temat tzw. formuły Radbrucha, która ma pomóc rozstrzygnąć konflikt między elementami idei prawa: najczęściej zachodzący jednak między bezpieczeństwem a sprawiedliwością. Po II wojnie światowej doszło do drugiego odrodzenia teorii prawa natury. Zapoczątkował je G. Radbruch, z jednej strony występując przeciwko ustawowemu bezprawiu, z drugiej zaś broniąc ponadustawowego prawa. Związana z tym jego słynna myśl zakłada, że lex iniustissima non est lex (prawo niesprawiedliwe nie jest prawem). Zgodnie z powyższym podejściem nie zawsze obowiązujące prawo należy utożsamiać ze sprawiedliwością. Wojciech Zalewski, autor drugiego podrozdziału, snuje refleksje nad modelem sprawiedliwości naprawczej, znaczeniem mediacji i jej wpływem na kształt procesu oraz bezwzględnego stosowania zasady dura lex sed lex, co przejawia się również w kilku późniejszych rozdziałach.

W rozdziale II (Prawo kontra moralność) Jarosław Warylewski analizuje szczegółowo zagadnienie pornografii i przestępstw seksualnych, odwołując się do głosów i komentarzy na ten temat, rozmaitych autorytetów z dziedziny prawa karnego, takich jak np. M. Filar, A. Marek, R. Góral, A. Szymański, O. Górniok. Prezentuje dane statystyczne zebrane w Polsce, związane z omawianymi zagadnieniami, w tabelach (4) i wykresach (2). Na uwagę zasługuje postulat wciąż niewprowadzonej edukacji seksualnej w polskich szkołach, jak można wywnioskować po wypowiedzi autora. I choć mówi się wiele o pornografii w naszym kraju, to jednak nie o edukacyjnym i terapeutycznym jej wpływie (s. 51). Drugi tekst tego rozdziału porusza problematykę wartości życia ludzkiego i jego absolutnego, czy też może nieabsolutnego charakteru. Jego autorzy, Nicolas Cieslewicz i Oktawian Nawrot przywołują bardzo kontrowersyjne przypadki związane z prawem do życia i coraz częstszymi głosami na rzecz prawa do godnej śmierci (śmierci na życzenie, odłączenia od aparatury podtrzymującej życie itp.). Przywołując poglądy moralne na temat życia i śmierci, autorzy pragną skłonić czytelników do zastanowienia się nad wyborem, czy cywilizacja życia, czy cywilizacja śmierci, które przeciwstawia zwłaszcza Kościół rzymskokatolicki. Inne podejście do sprawy znane jest dzięki poglądom stoików, zwłaszcza Lucjusza Anneusza Seneki, którego myśl zapadła mi niegdyś w pamięci: Non est bonum vivere, sed bene vivere (Nie samo życie jest dobrem, ale dobre życie). Problem jednak pozostaje w określeniu, co to znaczy owo dobre życie, podobnie jak na podstawie tegoż podrozdziału, co to znaczy dobra śmierć? 
W rozdziale III (Prawo kontra obyczajowość) autorzy rozważają trudne przypadki prawa w wyniku różnic kulturowych. Najpierw J. Zajadło rozważa problem kulturowej neutralności, czy zaangażowania prawa, a następnie Jarosław Warylewski, który we wcześniejszym rozdziale (Prawo kontra moralność) badał zagadnienie pornografii, w tym rozdziale podejmuje się analizy dotyczącej kazirodztwa również w kontekście wolności seksualnej. Dokonując krótkiego rysu historycznego kazirodztwa, autor prezentuje głosy na temat jego penalizacji oraz wypowiada swoje stanowisko w tej sprawie, postulując jego dekryminalizację, wyżej ceniąc ochronę wolności jednostki niż obyczajowości (s. 88).

W rozdziale IV (Prawo kontra religia) Oktawian Nawrot przypomina jeden z najsłynniejszych procesów w historii o podłożu religijnym (zob. Edward Knappman, 100 najsłynniejszych procesów, tłum. J. Mikos, „Świat Książki”, Warszawa 1998), związany z postacią Sokratesa. Swoje rozważania autor opiera głównie na platońskim dialogu, Obrona Sokratesa, który w polskim tłumaczeniu Władysława Witwickiego i jego znakomitymi objaśnieniami jest fundamentalnym źródłem w tej do dziś analizowanej sprawie. Interesującym wątkiem jest zwrócenie uwagi na polityczny charakter dialogu mający związek z sokratejską krytyką i dezaprobatą dla ateńskiej demokracji. Warto przywołać tutaj całkiem nową pozycję, ujmującą proces Sokratesa z innej strony, a mianowicie pracę amerykańskiego dziennikarza (I. F. Stone, Sprawa Sokratesa, tłum. L. Jęczmyk, Zysk i S-ka, Poznań 2003), która kładzie cień na postać Sokratesa widzianą dotąd przez pryzmat dialogów Platona. Niemniej jednak stanowisko Stone’a potwierdza tylko fakt, jak bardzo skomplikowana była sprawa dotycząca oskarżenia, procesu i skazania na śmierć Sokratesa. Z perspektywy współczesnej demokracji wypada chyba powiedzieć, że Sokrates nie krytykował demokracji za to, że jest, ale za to jaka jest, a raczej jaka była w znanych mu Atenach. Gdyby rządzili, czyli byli wybierani na stanowiska, niekoniecznie w drodze losowania naprawdę najlepsi - to raczej „ten najmądrzejszy ze wszystkich ludzi” jak głosiła wyrocznia w Delfach - nie miałby do niej zastrzeżeń. Sokrates jako krytyk demokracji ateńskiej, przez swój proces i śmierć w imię wolności światopoglądowej stał się nie tylko archetypem filozofa na kolejne wieki, ale także prawdziwym obrońcą demokracji w ujęciu współczesnym. Z kolei Wojciech Cieślak w podrozdziale zatytułowanym Pasja przed sądem omówił głośną, zwłaszcza w polskich mediach, sprawę artystki Doroty Nieznalskiej, oskarżonej o obrazę uczuć religijnych podczas wystawy „Pasja” w gdańskiej Galerii Wyspa Progress. Co ciekawe, autor był adwokatem artystki, znał więc sprawę z tzw. pierwszej ręki. Przedstawił ją w sposób obiektywny, eksponując przy tym to, co było w niej najtrudniejsze z punktu widzenia obowiązywania prawa i budziło dodatkowo, zwłaszcza poza salą sądową, tak wiele niepotrzebnych emocji.

Już we wstępie do kolejnego, piątego rozdziału (Prawo kontra nauka) J. Zajadło wyjaśnił, że „nie chodzi w nim o bezpośredni konflikt prawa z nauką, co raczej o odpowiedź na [...] pytanie: czy rozwój prawa nadąża za postępem naukowo-technicznym? Oraz czy prawo jest skutecznym instrumentem bilansowania korzyści i zagrożeń wynikających z rozwoju nauki i techniki?” (s. 114). Być może po zapoznaniu się z dwo- 
ma stanami faktycznymi przedstawionymi w jego podrozdziałach lepszy byłby np. tytuł: Prawo kontra postęp technologiczny, jako że nauka jest pojęciem bardzo szerokim i obok nauk matematyczno-przyrodniczych może dotyczyć także nauk humanistycznych i innych niezwiązanych zupełnie z technologią. Autorami podrozdziałów są specjaliści z zakresu prawa międzynarodowego publicznego. Jako pierwsza - Dorota Pyć ujmuje rozwój współczesnej energetyki jądrowej w szerszym kontekście ochrony środowiska naturalnego. W perspektywie tego rozwoju, który wydaje się nieunikniony w aspekcie globalnym, bezpieczeństwo ma być „sensem” energetyki jądrowej (s. 120). Prawo, jej zdaniem, jawi się jako coś, co w sposób racjonalny i wyważony zapewni maksimum korzyści z energii atomowej przy minimalnym zagrożeniu z jej strony. Autorka obok literatury specjalistycznej opiera się na źródłach, do których zalicza m. in.: Decyzje Komisji Euratom, Komisji Europejskiej, różne dyrektywy, komunikaty i zalecenia związane z wykorzystywaniem energii jądrowej (s. 124). Najwięcej uwagi poświęca jednak prowadzeniu wspólnej polityki energetycznej w ramach Unii Europejskiej, w tym Polski jako jednemu z siedmiu krajów członkowskich pozostających jak na razie bez elektrowni atomowych. Z kolei Maciej Barczewski omawia hard case związany z jednej strony z koniecznością ochrony praw autorskich wynikających z twórczości naukowej, literackiej i artystycznej, z drugiej zaś z prawem do korzystania z dóbr kultury i osiągnięć postępu naukowego (s. 128 i 129). Uściślenia wymaga chyba podanie roku 1450, jako bardziej prawdopodobnego, niż wskazany rok 1440 (s. 127), w którym to Johann Gutenberg miał wynaleźć czcionkę drukarską. Aczkolwiek trudno jest tutaj wskazać datę dzienną tego wydarzenia, ale już na pewno można podać datę wydania pierwszej książki w tej technice, czyli 42-wierszowej Biblii z 1455 r.

W rozdziale VI (Prawo kontra medycyna), a więc w połowie omawianych trudnych przypadków z pogranicza prawa i jakiegoś innego systemu normatywnego, J. Zajadło w swoim wprowadzeniu podkreśla niezwykle istotną rzecz z nimi (tzn. hard cases) związaną, a mianowicie: „zderzenie prawa z medycyną jest zagadnieniem wielopłaszczyznowym [podkreślenie moje - K.K.] i dotyczy także innych sfer powstawania «trudnych przypadków», np. styku prawa i nauki, prawa i ekonomii, prawa i religii etc." (s. 132). Owa wielopłaszczyznowość przenika właściwie wszystkie dotychczasowe rozdziały, będzie też obecna w następnych rozdziałach. Oktawian Nawrot Miecz Salomona rozpoczyna od cytatu z Biblii opisującego słynny, mądry i sprawiedliwy zarazem wyrok króla Izraela na kobiety spierające się o dziecko (s. 133). Stanowi to znakomite wprowadzenie do ukazania istoty trudnych przypadków związanych z macierzyństwem zastępczym. Szczególnego znaczenia nabierają jego rozważania na temat rodzajów macierzyństwa i relacji, jakie mogą się tutaj pojawić, między prawem matki genetycznej, biologicznej i socjologicznej do dziecka (s. 136-137), którego dobro jest lub raczej powinno być zawsze nadrzędnie traktowane przy tego typu sądowych rozstrzygnięciach. Autor kolejnego podrozdziału zatytułowanego Kogo nie stać na zdrowie jako meritum omawianego hard case podaje „rozbieżność między potrzebą ochrony interesów majątkowych oraz zapewnienia prawa do odpowiedniego leczenia..." (s. 147). Autor formułuje wymowną 
antynomię: „zysk kontra życie”, która ma bardzo aktualny wydźwięk zarówno w wymiarze globalnym, jak i typowo polskim i dotyczy wciąż nierozwiązanych problemów publicznej służby zdrowia.

W rozdziale VII (Prawo kontra historia) autorzy analizują dwa trudne przypadki, które można określić jako po pierwsze, historia przed sądem karnym, po drugie, historia przed sądem cywilnym (s. 154 i następne). Oba przypadki dotykają problemu tzw. sprawiedliwości retrospektywnej i wiążą się z szerszym zagadnieniem polityki wobec przeszłości. W pierwszym podrozdziale J. Zajadło prezentuje w skrócie swoje rozważania zawarte w książce Odpowiedzialność za Mur. Procesy strzelców przy Murze Berlińskim, Gdańsk 2003, do których doszło w Niemczech po zjednoczeniu. W drugim podrozdziale, Bractwie uwięzione w college’u, Kamil Zeidler zwraca uwagę na czekającą wciąż na rozwiązanie kwestię zwrotu polskich dóbr kultury i dziedzictwa narodowego, znajdujących się na skutek różnych okoliczności poza granicami kraju. Jako przykład podaje losy kolekcji polskiej sztuki, tj. obrazów przedwojennych artystów zorganizowanych w Bractwo Św. Łukasza z Kazimierza Dolnego nad Wisłą, znajdujących się do dziś w Le Moyen College w Syracuse (USA). Autor podaje przykłady kompromisowych i godziwych sposobów rozwiązania sporu. W rezultacie postuluje bardziej stanowcze działania władz RP w tej sprawie, której wygranie przed sądem amerykańskim „mogłoby stać się - jego zdaniem - precedensem, czyli solidną podstawą normatywną dla dochodzenia innych tego typu roszczeń" (s. 170).

W rozdziale VIII (Prawo kontra polityka) autorzy zajmują się, zdaniem redaktora książki, zderzeniem „najgroźniejszym dla samego prawa” (s. 175). Jako prawnicy zgłaszają obawy przed dominacją polityki nad prawem, czego wyrazem ma być instrumentalne traktowanie prawa. W podrozdziale Poczekamy, az się wymordujecie Sebastian Sykuna najpierw opisuje poczynania wspólnoty międzynarodowej, głównie ONZ, na zatrważające społeczność międzynarodową w latach 90. walki o podłożu plemiennym w Rwandzie, a następnie interwencję wojsk NATO w Kosowie. Bada przesłanki legitymizujące tzw. interwencje humanitarne i ich zasadność z punktu widzenia prawa międzynarodowego. Z kolei konstytucjonalista Piotr Uziębło w podrozdziale Spóźniony - bez mandatu rozważa sprawę spóźnionego składania oświadczeń majątkowych funkcjonariuszy samorządowych w kontekście polskich wyborów z 2006 r. W konkluzji autor broni w zasadzie stanowiska zajętego przez Trybunał Konstytucyjny w tej sprawie. Jego ocena sprowadza się do tego, że choć pokusa postawienia polityki nad prawem „staje się na porządku dziennym" nawet w demokratycznym państwie prawa, to nigdy nie może to być prymat polityki nad prawami i wolnościami jednostki, które są w takim państwie najważniejsze (s. 193 i 198).

W rozdziale IX (Prawo kontra media) Wojciech Zalewski przypomina głośną medialnie sprawę słynnego, byłego gwiazdora futbolu amerykańskiego O. J. Simpsona, oskarżonego o zabójstwo swojej żony i jej kochanka. Autor ukazał sprawę sportowca jako trudny przypadek, który dzięki mediom, głównie telewizji, relacjonowany był na żywo społeczeństwu. Począwszy od jego spektakularnej ucieczki przed policją i schwytania, aż po wydanie jednomyślną decyzją ławy przysięgłych wyroku uniewinniającego. Inte- 
resującym wątkiem, który starał się uwypuklić autor jest rasowy podtekst całej sprawy (kolorowy mąż oskarżony o zamordowanie białej żony). Miało to wpływ na dobór przysięgłych i zróżnicowane odczucia społeczne, wyrażane w sondażach przez Amerykanów białych i kolorowych. Autor drugiego z podrozdziałów - Adam Wiśniewski, opisuje jako hard cases dwa przypadki związane z mediami i ich rolą społeczną. Najpierw sprawę księżniczki Caroline von Hannover, która wyszła zwycięsko z sądowej batalii: wolność mediów a jej prawo do ochrony życia prywatnego (s. 210-214), a następnie duńską sprawę Jersild, ukazującą rzeczywiste dylematy i napięcia zachodzące, jak wcześniej, między zasadą wolności mediów a potrzebą ochrony przed dyskryminacją rasową związaną $\mathrm{z}$ tzw. hate speech, czyli mową nienawiści (s. 214-217).

W rozdziale X (Prawo kontra ekonomia) Janina Ciechanowicz-McLean analizuje przypadki sporów o przeprowadzenie obwodnic w dwóch podlaskich miejscowościach: Augustowie i Wasilkowie. Autorka rozważa problematykę nadrzędnego interesu publicznego jako alternatywnego wyboru między zapewnieniem bezpieczeństwa i rozwoju ekonomicznego lokalnych społeczności a ochroną środowiska naturalnego. Przedstawiając obiektywnie racje obu stron, autorka w imię „zrównoważonego rozwoju” (s. 226) zachęca do szukania i wypracowania kompromisu, choć jest to mało prawdopodobne, szczególnie w przypadku obwodnicy Augustowa przez dolinę Rospudy. Jako mieszkaniec województwa podlaskiego wierzę, że uda się ów kompromis osiągnąć, a rozpoczęte już budowy zostaną dokończone. Jednakże powinniśmy zdać sobie sprawę z nieuchronnego faktu, iż dróg i poruszających się po nich ludzi będzie coraz więcej, natomiast środowiska naturalnego, niezakłóconego przez człowieka coraz mniej. Wniosek, jaki można na tej podstawie wyprowadzić, wydaje się przynajmniej w aspekcie globalnym oczywisty. Zmiany w środowisku mogą być nieodwracalne, nad czym będą ubolewać przyszłe pokolenia. W podrozdziale autorstwa Magdaleny Konopackiej opisana jest kontrowersyjna sprawa związana z tzw. ekonomiczną analizą prawa. Na podstawie precedensowego wyroku sądu amerykańskiego wprowadzono „zasadę Laidlaw”, zakładającą „jednostka ma prawo czerpać zyski z dokonywania transakcji na podstawie tajnych informacji, które pewnego dnia mogą dotrzeć do rynku w inny sposób” (s. 233). Jak podaje autorka, sędzia w tej trudnej sprawie odrzucił rozumowanie Cycerona przeciwstawiające się „praworządności dla zysku”, która zdaniem rzymskiego prawnika - jest najbardziej niesprawiedliwa (s. 232). Innymi słowy, z czystym zyskiem ekonomicznym w ramach gospodarki liberalnej bardzo trudno w praktyce wygrać, broniąc tak niejednoznacznych wartości wyższych, jak np.: uczciwość, szczerość, szlachetność czy sprawiedliwość społeczna. Filozofia prawa odwołująca się do prawa natury stawia jednak bardzo wysoko poprzeczkę, ucząc szacunku do wartości wyższych, zwanych ideami, a których nośnikiem jest prawo. Przecież zgodnie ze słynną łacińską premią: Ius est ars boni et aequi (Prawo jest sztuką stosowania tego, co dobre i słuszne), ale czy taką samą sztuką jest również lex. Na opisanym w książce przykładzie wydaje się, że nie.

Rozdział XI (Prawo kontra ekologia) jest kolejnym przykładem pojawienia się rozbieżności na wielu liniach: ekologia-ekonomia-nauka-polityka, które warunkują hard cases, mających w istocie charakter pozaprawny (s. 238). Zdaniem J. Zajadło, jedna 
z autorek podrozdziału - Janina Ciechanowicz-McLean, postąpiła dosyć „przewrotnie”, umieszczając we wcześniejszym rozdziale $\mathrm{X}$, jako trudny prawno-ekonomiczny, przypadek wydawałoby się typowo ekologiczny, gdyż związany z doliną Rospudy. W tym rozdziale natomiast sprawę gazociągu bałtyckiego potraktowała à rebours w kategoriach ekologicznych, choć mogła to również zrobić w kategoriach ekonomicznych (s. 238). Zabieg taki należy ocenić jak najbardziej pozytywnie, ponieważ dodatkowo uświadamia on nam interdyscyplinarną zawiłość trudnych przypadków, których rozwiązanie wymaga wielopłaszczyznowego podejścia. Wydaje się, że najlepszym wyjściem z sytuacji powinna być wspólna polityka energetyczna w ramach Unii Europejskiej. W nawiązaniu do wcześniejszego tekstu autorki o sporze ekologów ze społecznościami lokalnymi $\mathrm{w}$ sprawie obwodnic, istotnym zagadnieniem także w sprawie rury na dnie Bałtyku staje się terroryzm ekologiczny. W tym kontekście szczególnego znaczenia nabiera odróżnienie pojęcia ekoterroryzmu - fanatycznych obrońców środowiska, od terroryzmu ekologicznego jako zagrożenia np. ze strony zamachowców chcących doprowadzić do katastrofy ekologicznej (por. s. 226 i 246). Druga autorka - Dorota Pyć, opisuje morskie katastrofy ekologiczne przyczyniające się do udoskonalenia prawa międzynarodowego publicznego (głównie prawa morskiego oraz prawa międzynarodowego zarządu morską flotą handlową) pod kątem zapewnienia bezpieczeństwa i ochrony środowiska. Według niej, stworzenie europejskiej strategii zintegrowanego systemu morskiego (s. 255) prowadzi w konsekwencji do zaostrzenia przepisów i wzmożenia kontroli mających na celu zminimalizowanie wszelkich zagrożeń. Po przeczytaniu podrozdziału nie pozostaje nic innego, jak tylko życzyć, by wysokie standardy europejskie w tej kwestii stały się wyznacznikiem dla innych państw na świecie. W przeciwnym razie europejskie starania mogą nie mieć sensu.

W rozdziale XII (Prawo kontra etyka prawnicza) przedstawione są sprawy, których rozstrzygnięcie wymaga zaangażowania rozumu praktycznego (s. 261). Rozum praktyczny, jak wiemy, szukał, zdaniem Kanta, odpowiedzi na pytanie: co powinienem czynić? Uznając powinność, czyli postępowanie jedynie $\mathrm{z}$ obowiązku, a nie zgodne $\mathrm{z}$ obowiązkiem, za warunek moralnego postępowania. W pierwszym podrozdziale poruszono problematykę doradztwa prawnego dla władz publicznych na przykładzie Stanów Zjednoczonych. Opisany stan faktyczny dotyczył doradcy rządowego, który wskazał warunki ominięcia prawa i odpowiedzialności za stosowanie tortur przez służby amerykańskie, podczas tzw. wojny z terroryzmem. Autor odwołał się do najważniejszych głosów w dyskusji na ten temat, jakie pojawiły się w doktrynie amerykańskiej. Abstrahując jednak od wątków typowo amerykańskich, szczególną wartość w tym podrozdziale mają zasady dobrego doradztwa dla władz publicznych sformułowane przez J. Zajadło (s. 271). Ich głównym zadaniem jest wypracowanie obiektywnych przesłanek oceny trudnych sytuacji, mających zapewnić transparentność działań i odpowiedzialność za nie - władz publicznych. W drugim podrozdziale o wymownym tytule - pytaniu: Zabić Hitlera?, Sebastian Sykana podejmuje problemy związane z etyką adwokacką. Odwołuje się przy tym do wielu aktów normatywnych, od konstytucji począwszy, a na Zbiorze Zasad Etyki Adwokackiej i Godności Zawodu kończąc. W większości teoretyczne rozważania autora 
mają uświadomić czytelnikowi, jak trudne w praktyce, zwłaszcza z etycznego punktu widzenia, jest wykonywanie zawodu adwokata.

W ostatnim rozdziale XIII (Prawo kontra zdrowy rozsądek) Wojciech Zalewski analizuje teorie przyczynowości i związane z nią problemy warunkujące trudne przypadki. Przedstawia rys historyczny rozumienia przyczynowości w polskiej doktrynie, głównie prawa karnego. W tym najtrudniejszym chyba podrozdziale książki autor w kompetentny sposób poszukuje najlepszego rozwiązania, upatrywanego w teorii tzw. obiektywnego przypisania. Z kolei Anna Machnikowska, tym razem z pozycji zdrowego rozsądku, bada sprawę opóźnionego złożenia oświadczeń majątkowych przy wyborach samorządowych aż przez ponad 760 osób w całym kraju (s. 296). Podobny stan faktyczny, jako rodzący hard case, analizował w odniesieniu do polityki, w rozdziale VIII - Piotr Uziębło. Anna Machnikowska odwoływała się do koncepcji zdrowego rozsądku w rozumieniu T. Reida, a także J. Locke’a i I. Kanta. Według niej zdrowy rozsądek zajmuje ważne miejsce w kulturze prawnej, która z niego korzysta. Autorka położyła nacisk na wyjaśnienie zasad, którymi kierował się Trybunał Konstytucyjny wydający orzeczenie korzystne dla samorządowców (s. 301). Za najważniejszą z przesłanek TK uznał ochronę praw i wolności obywatelskich „w zestawieniu z interesem publicznym, w którym miały one swój istotny dział” (s. 301). Sędziowie, świadomi konieczności szacunku dla obowiązującego prawa (dura lex sed lex) i zasady legitymizmu, zdawali sobie sprawę z irracjonalności całej sytuacji. Jako ostateczność brali pod uwagę możliwość przeprowadzenia ponownych wyborów, które byłyby trudne do zrozumienia w odczuciu przeciętnego człowieka.

W zakończeniu noszącym tytuł Prawo kontra człowiek J. Zajadło jeszcze raz przywołuje przypadek związany ze stosowaniem tortur, obecnie chyba najtrudniejszy z przypadków (the hardest case) (s. 311). W podrozdziale zatytułowanym Tortury wysterylizowane stara się na podstawie różnych głosów uchwycić zasadniczą w tym przypadku różnicę między torturami a okrutnym traktowaniem (s. 315). Podaje możliwe stanowiska w tej sprawie - od akceptacji tortur, przez ich dopuszczenie pod pewnymi tylko warunkami (np. sądowe upoważnienie), aż po bezwzględny ich zakaz, co wiąże się z ochroną praw człowieka i poszanowania godności ludzkiej. Czyżby istniały techniki torturowania, które nie byłyby zarazem okrutne, nieludzkie i poniżające? Pewne głosy mówią, że tak - odwołując się np. do stanu wyższej konieczności, zapewnienia bezpieczeństwa zbiorowego, czy nawet tortur jako wyboru mniejszego zła. Wydaje się, że precyzyjniejsze, niż imperatyw kategoryczny, byłoby podanie imperatywu praktycznego jako kantowskiego nakazu bezwzględnego traktowania każdego człowieka zawsze jako celu, nigdy jako środka (s. 318). Niemniej jednak wiadomo, że imperatyw praktyczny („Postępuj tak, byś człowieczeństwa tak w twej osobie, jako też w osobie każdego innego używał zawsze zarazem jako celu, nigdy tylko jako środka” - I. Kant, Uzasadnienie metafizyki moralności, tłum. M. Wartenberg, Warszawa 1981, 1984, s. 62) jest jednym z wielu rodzajów imperatywu kategorycznego, z którego wynika, a który stanowi fundament deontologicznej etyki Kanta. Ostatni podrozdział książki autorstwa Zdzisława Brodeckiego, noszący angielski tytuł: Do hard cases make bad law?, potwierdza przeczącą odpowiedź na zawarte w nim pytanie. Hard cases make good law - trudne przypadki w rzeczywistości przyczy- 
niają się do powstania dobrego prawa, które to prawo rozwijają (s. 328). Podsumowując, autor snuje refleksje na temat prawa naturalnego i praw człowieka. Pisze, ze pierwsza generacja tych praw obejmuje swym zasięgiem prawa osobiste i polityczne, i wiąże się z wartością godności, wolności i własności przysługujących każdej jednostce ludzkiej (s. 324-325). Druga generacja praw człowieka nawiązuje do idei równości (prawa socjalne, ekonomiczne i kulturowe), trzecia zaś do idei solidarności (s. 325). „Dekompozycja trzech generacji praw człowieka powinna być dokonana - zdaniem autora - z myślą o konieczności rozstrzygnięcia konfliktu między prawami jednostki (humanitaryzmem) a obowiązkami wobec zbiorowości (efektywnością, racjonalizmem)”. W tym kontekście sprawiedliwy sędzia rozstrzygający trudne przypadki „to ktoś, kto potrafi znaleźć złoty środek w sporze między liberałami a komunitarianami, między prawami a obowiązkami" (s. 235).

Z całym przekonaniem można powiedzieć, że książka, co sugeruje tytuł, jest równie fascynująca, jak zawarte w niej i opisane różne ścieżki filozofii prawa. Publikacja ma uniwersalne przesłanie, ponieważ opisane w niej stany faktyczne zawsze będą służyć jako przykłady rozwiązywania trudnych przypadków. Jej interdyscyplinarny charakter potwierdza konieczność uczenia szerokiego patrzenia na świat adeptów prawa i to z różnych punktów widzenia. Ma przy tym ogromną wartość dydaktyczną, zwłaszcza dla filozofii prawa, ale także innych przedmiotów i to nie tylko prawniczych. Pokazuje bowiem, jak ważne z punktu widzenia praktyki jest nauczanie filozofii prawa, która ma pomóc w ukształtowaniu dobrego, mądrego i odpowiedzialnego prawnika.

Podsumowując bogactwo problematyki poruszonej w książce, można nawet powiedzieć, że we wszystkich jej rozdziałach przewija się jako chyba dominujący wątek: prawo kontra bardzo szeroko rozumiana wolność. Jej ogólne przesłanie potwierdza odwieczne przekonanie ludzi zajmujących się i związanych z prawem, że sprawiedliwość zawsze idzie w parze z mądrością. Jako przykład można tutaj przytoczyć biblijną Księgę Mądrości (8, 7-8), w której napisano, że dla tego, kto miłuje sprawiedliwość, dziełem Mądrości są cnoty. Mądrość „uczy bowiem umiarkowania i roztropności, sprawiedliwości i męstwa, od których nie ma dla ludzi nic lepszego w życiu”. O podobnej drodze i konieczności namysłu filozoficznego przez prawników, w dziele $O$ prawach (I, 5, 17-1) Cyceron pisał: „Nie z edyktu pretora, jak wielu dzisiejszych prawników, ani z Ustawy XII tablic, jak dawniejsi, ale ze źródeł najgłębszej filozofii czerpać trzeba naukę prawa”. Wskazując na nierozerwalny i ścisły związek mądrości i sprawiedliwości, po przeczytaniu niniejszej książki należy powiedzieć, że prawdziwy miłośnik sprawiedliwości jest jednocześnie miłośnikiem mądrości, co zgadza się z założeniem autorów i redaktora, iż przy rozwiązywaniu hard cases należy uprawiać filozofię prawa, przede wszystkim „od prawa ku filozofii”, wiedząc jednak, że istnieje także sposób wiodący „od filozofii ku prawu” (s. 16). Miejmy nadzieję, że książka zostanie życzliwie przyjęta, przyczyniając się do poszerzenia horyzontów myślowych czytelników. 